\title{
Therapeutic Efficiency of Centella Asiatica Flour Incorporated Fryums
}

\author{
Saranya Kulasekaran¹, Dr. Yamuna Devi Puraikalan² \\ ${ }^{1}$ Postgraduate Research Scholar, Department of Home Science, Mother Teresa Women's University, Kodaikanal, India \\ ${ }^{2}$ M.Phil., Phd, Assistant Professor, Department of Home Science, Mother Teresa Women's University, Kodaikanal, India
}

\begin{abstract}
The present study was to formulate the Centellaasiatica flour incorporated fryums by incorporation of different level of Centellaasiatica flour like $5 \%, 10 \%$ and $15 \%$ into fryums. The Organoleptic properties of the formulated fryums like colour, appearance, flavour, crispiness, taste and over all acceptability were evaluated. Among the different incorporation $10 \%$ of Centellaasiatica flour incorporated fryums were recorded the highest scores for overall acceptability.
\end{abstract}

Keywords: Centellaasiaticaflour, Centella,C.asiatica, Vitamin-C and Triterpenoids

\section{Introduction}

Centellaasiatica (C.asiatica, Centella) is a prostrate, faintly aromatic, stoloniferous, perennial, creeper herb, attains height up to $15 \mathrm{~cm}$ (6 inches). The Centellaasiatica belongs to the family Apiaceae or Umbelliferae, and flourishes in wet areas of Malaysia, Indonesia, India, and other parts of Asia including China. Utilization of Centellaasiatica (C.asiatica) have been known for many years in treating all kind of diseases such as gastrointestinal disease, gastric ulcer, asthma, wound healing and eczema [1].

Centellaasiatica found throughout tropical and subtropical regions of India up to an altitude of $600 \mathrm{~m}$. The plant is indigenous to SouthEast Asia, India, and Sri Lanka, parts of China, the Western South Sea Islands, Madagascar, South Africa, South East USA, Mexico, Venezuela, Columbia and Eastern South America[2].

In India and other Far East countries, C.asiaticais traditionally used in the form of cover crop in rubber and tea plantations. It

is also one of the constituents of summer drink popularly known as thandaayee. Besides, C.asiatica is generally eaten as green leafy vegetable in the form of salad and ulam among the Malay and Javanese people[3].

Centella is useful for the antioxidant effect as it offer an effective and safe way of increasing body immune system against free radicals [4] and at the same time keep the oxidative stress in a state of balance. Among the triterpenes isolated from Centella plant, asiaticoside is the most abundance and responsible to stimulate antioxidant activity in the early phase of the wound healing process[5]. Asiaticoside has been reported to decrease fibrosis in wounds, thus preventing new scar formation.C.asiatica is one of the chief herbs for treating skin problems, to heal wounds, for revitalizing the nerves and brain cells, hence primarily known as a "Brain food" in India[6].

The C.asiaticahas excellent nutritive value. The total calories in $100 \mathrm{~g}$ of Centella are $37.0 \mathrm{Kcal}$. In general, Centella contained high concentration of potassium (391 $\mathrm{mg}$ ) and calcium (171 mg), low in protein (2.0\%), carbohydrate $(6.7 \%)$ and fat $(0.2 \%)$. It also contains $87.7 \%$ moisture, $1.6 \%$ crude fiber, $1.8 \%$ ash, (32.0 mg/100 g) phosphorus, (5.6 mg/100 g) iron and (21 mg/100 g) sodium. Centella is also rich in vitamin C (48.5 mg/100 g), B1 (0.09 $\mathrm{mg} / 100 \mathrm{~g})$, B2 (0.19 mg/100 g), niacin (0.1 mg/100 g), carotene (2649 $\mu \mathrm{g} / 100 \mathrm{~g})$ and vitamin A (442 $\mu \mathrm{g} / 100 \mathrm{~g})[7]$.

They also find out that C.asiatica is a good source of antioxidants like ascorbic acid, total and beta carotene and total phenolics[8], also studied the antioxidant contents and antioxidant activity of Centellaasiaticacultivated in India. Their results showed that C.asiatica had a good antioxidant activity and good source of antioxidant contents. Asiatic acid in C.asiatica was found to have anticancer effect on skin cancer. Asiaticosides possesses good wound healing activities because of its stimulative effect on collagen synthesis. It might be useful in cancer chemotherapy as it induces apoptosis and enhances antitumour activity of vincristine in cancer cells.

The use of C.asiatica in food and beverages has increased over the years basically due to its health benefits such as antioxidant, as anti-inflammatory, wound healing, memory enhancing property and many others. The potential of C.asiatica as an alternative natural antioxidant especially of plant origin and its protection against age-related changes in brain antioxidant defense system, have notably increased in recent years[9]. The Centella aqueous extract also demonstrated very promising results in protecting the brain against neurodegenerative disorders such as Parkinson[10].Centella extract had shown positive modulation of cognition function and improvement of selfrated mood after 2 months of taking the extract at $750 \mathrm{mg}$ daily[11].

\section{Materials and Methods}

Fresh leaves of Centellaasiatica were selected for the preparation of the Centellaasiaticaflour. C.asiaticaleaves were initially cleaned and washed with water. The stem part was also includes for its nutritional constituents and whole leaf with stems were dried in shade. The dried C.asiaticaleaves were grinded as flour in the processor and 


\section{International Journal of Science and Research (IJSR) \\ ISSN (Online): 2319-7064 \\ Index Copernicus Value (2013): 6.14 | Impact Factor (2015): 6.391}

made it cool and incorporated into fryums with different level of incorporation. The products were stored in a hygienic manner. The treatments for preparation of Centellaasiaticafryums were as follows;

\section{Treatment Details}

T1 - Rice flour (Control)

$\mathrm{T} 2$ - Rice flour $+5 \%$ of Centellaasiatica flour

T3 - Rice flour $+10 \%$ of Centellaasiaticaflour

$\mathrm{T} 4$ - Rice flour $+15 \%$ of Centellaasiatica flour

The formulated fryums were prepared with specified amount of C.asiaticaflour as mentioned in above treatments. All the ingredients such as rice flour, oil, green chillies, cumin seeds and salt were used.

Organoleptic evaluation of Centellaasiatica flour incorporated fryums were carried out by 10 am among the semi-trained panel judges of thirty numbers including the staff and post-graduate nutrition students, Department of Home science, Mother Teresa Women's University, and Women's Christian College, Chennai. The Centellaasiaticaflour incorporated fryums were placed for onset evaluation. The specific sensory characteristics of fryums viz., crunchiness, porosity, surface hue, surface adhesiveness with other general characteristics viz., colour, aroma, taste, mouth feel and over all acceptability were evaluated using a rating scale. The mean Scores given by sixty judges were used for statistical analysis.

\section{Result and Discussion}

The Organoleptic properties of fryums were evaluated visually, palpatory, gustatory, olfactory, and overall acceptability. The statistical analyses of the data were depicted in the Table I. The overall acceptability and 9 point rating scale score was higher for the $10 \%$ incorporation of C.asiatica flour. The data reveals that there were significant differences at the level of $1 \%$ significances among $10 \%$

\section{Conclusion}

The extensive popularity of fryums from all age groups makes this product, a good option for selection. It improves vitamin-C and Phytochemicals and significant protection for lowered the blood glucose levels to normal in glucose tolerance test. It is effective in the management of mild cognitive impairment and other related age-related problems of elderly people such as improvement of diastolic blood pressure, peripheral neuritis, insomnia and loss of appetite. Asiatic acid in C.asiatica was found to have anticancer effect on skin cancer. This formulated fryums is convenience food can surely serve as suitable vehicle for improving nutrient intake without compromising its organoleptic properties. It will indirectly improve the vitamin-C, carotene and Phytochemical intake of its consumers. The product has excellent market potential since it contain low carbohydrate, high protein, high vitamin-C, carotenes and phytochemical, and sufficient amount of vitamin and mineral content. Considering all these beneficial factors the C.asiatica flour based other products must be of most concern. New steps must be taken to undergo research about nutritive value of Centellaasiatica plant and its part and to introduce it to all community.

Table 1: Results of Statistical analysis of scores given by panel judges for the vitamin- $\mathrm{C}$ and Phytochemicalsrich C.asiaticaleaves incorporatedfryums

\begin{tabular}{|c|c|c|c|c|}
\hline S.No & $\begin{array}{c}\text { Level of } \\
\text { incorporation }\end{array}$ & Mean \pm S.D & t-value & $\begin{array}{c}\text { Level of } \\
\text { significance }\end{array}$ \\
\hline 1 & Control & $75.6 \pm 3.50$ & 3.71 & Not significant \\
\hline 2 & $5 \%$ & $74.4 \pm 3.38$ & 4.15 & Not significant \\
\hline 3 & $10 \%$ & $72.3 \pm 3.54$ & 2.02 & $1 \%$ \\
\hline 4 & $11 \%$ & $73.9 \pm 6.28$ & 3.55 & Not significant \\
\hline
\end{tabular}

\section{References}

[1] Brinkhaus, B., Lindner, M., Schuppan, D. and Hahn, E. G. 2000. Chemical, pharmacological and clinical profile of the East Asian medical plant Centellaasiatica. Phytomedicine 7: 427-428.

[2] Haleagrahara, N. and Ponnusanny, K. 2010. Neuroprotective effect of Centellaasiatica extract (CAE) on experimentally induced Parkinsonism in aged Sprague-Dawley rats. Journal of Toxicology Science 35: 41-47.

[3] Jamil SS, Nizami Q, Salam M. Centellaasiatica (Linn.): urban oA review. Natural Product Radiance, 6(2), 2007, 158-170.

[4] Noriham A, Babji AS, Aminah A (2004). Determination of antioxidative activities of selected Malaysian plant extracts. ASEAN. Food. J. 13: 193199

[5] Rajadurai, M. and Prince, P. S. M. 2006. Preventive effect of naringin on lipid peroxide and antioxidants in isoproterenol-induced cardiotoxicity in Wistar rats: biochemical and histopathological evidence. Toxicology 228: 259-268.

[6] Shukla A., Rasik A. K., Dhawan B.N., Asiaticoside induced elevation of antioxidant levels in healing wounds. Phytotherapy Research, 13: 50-54, (1999).

[7] Singh, R. H., Narsimhamurthy, K. and Singh G. 2008. Neuronutrient impact of AyurvedicRasayana therapy in brain aging. Biogerontology 9: 369-374.

[8] Subathra, M., Shila, S., Devi, M. A. and Panneerselvam, C. 2005. Emerging role of Centellaasiatica in improving age-related neurological antioxidant status. Experimental Gerontology 40: 707715

[9] Subhasree, B, Baskar. R, LaxmiKeerthana. R. Lijina Susan, R and Rajasekaran P. Evaluation of antioxidant potential in selected green leafy vegetables, Food Chemistry 2009; 115: 1213-1220.

[10] Tee, E.S., MohdIdris, N., Mohd Nasir, A. and Khatijah, I. 1997. Nutrient Composition of Malaysian Foods. 4th ed. Malaysian Food Composition Database Programme, p.16. Kuala Lumpur: Institute of Medical Research.

[11] Wattanathorn, J., Mator, L., Muchimapura, S., Tongun. T., Pasuriwong, O., Piyawatkul, N., Yimtae, K., Sripanidkulchai, B. and Singkhoraard, J. 2008. Positive modulation of cognition and mood in the healthy elderly volunteer following the administration of Centellaasiatica. Journal of Ethnopharmacology 116: 325-332. 


\section{International Journal of Science and Research (IJSR)}

ISSN (Online): 2319-7064

Index Copernicus Value (2013): 6.14 | Impact Factor (2015): 6.391

\section{Author Profile}

Saranya Kulasekaran received B.sc Degree in

Nutrition Food Service Management and Dietetics from Women's Christian College in 2014. Currently pursuing Postgraduate Degree in Foods and Nutrition from Mother Teresa Women's University. 